\title{
Computer-aided design of novel HIV-1 entry inhibitors blocking the virus envelope gp120 V3 loop
}

\author{
A. M. Andrianov ${ }^{1}$, I. V. Anishchenko ${ }^{2}$, M. A. Kisel ${ }^{1}$, Yu. V. Kornoushenko ${ }^{1}$, \\ V. A. Nikolayevich ${ }^{1}$, V. F. Eremin ${ }^{3}$, I. I. Kucherov', A. V. Tuzikov ${ }^{2}$ \\ ${ }^{1}$ Institute of Bioorganic Chemistry, NAS of Belarus \\ 5/2, Kuprevich Str., Minsk, Republic of Belarus, 220141 \\ ${ }^{2}$ United Institute of Informatics Problems, NAS of Belarus \\ 6, Surganova Str., Minsk, Republic of Belarus, 220012 \\ ${ }^{3}$ The Republican Research and Practical Center for Epidemiology and Microbiology \\ 23, Filimonova Str., Minsk, Republic of Belarus, 220114 \\ andrianov@iboch.bas-net.by; tuzikov@newman.bas-net.by; veremin@mail.ru
}

\begin{abstract}
Aim. The object of this study was to implement computer-aided design of the water-soluble analog of glycolipid $\beta$-galactosylceramide ( $\beta$-GalCer), which presents a potential HIV-1 entry inhibitor, by the analysis of intermolecular interactions of $\beta$-GalCer with the central region of the virus envelope gp120 V3 loop followed by synthesis of this glycolipid derivative and testing for antiviral activity. Methods. To reach the object of view, computer modeling procedures, such as quantum chemical calculations, molecular docking, molecular dynamics and free energy simulations, were involved in the studies in conjunction with chemical synthesis and anti-HIV-1 assay methods. Results. As a result, the high probability of exhibiting of antiviral activity was predicted for the designed $\beta$-GalCer analog. The data of molecular modeling were confirmed by those of primary medical trials of the synthesized compound. Conclusions. In the light of the findings obtained, the designed analog of $\beta$-GalCer may be considered as the basic structure for simulation of its more potent structural forms and for posterior selection of drug candidates most promising for synthesis and anti-HIV-1 assays.
\end{abstract}

Keywords: HIV-1 gp120 V3 loop, glycolipids, computer modeling, chemical synthesis, anti-AIDS drugs.

Introduction. The HIV-1 V3 loop plays a central role in the biology of the HIV-1 envelope glycoprotein gp120 as a principal target for neutralizing antibodies, and as a major determinant in the switch from the non-syncytium-inducing to the syncytium-inducing form of HIV-1 that is associated with accelerated disease progression. The HIV-1 cell entry is mediated by the sequential interactions of gp120 with the receptor CD4 and a co-receptor, usually CCR5 or CXCR4, depending on the individual virion, and the HIV-1 V3 loop is crucially involved in this process (reviewed in [1,2]). Although the V3 loop is a promising target for anti-HIV-1 drug design, its high sequence variability is a major complicating factor [3]. However, the latest findings obtained by

(C) Institute of Molecular Biology and Genetics, NAS of Ukraine, 2012 comparison of the 3D V3 structures in various HIV-1 isolates and different environments make it clear that the HIV-1 V3 loop forms a series of conserved structural motifs, which include residues crucial for cell tropism $[2,4-6]$. It is assumed that these V3 sites represent potential HIV-1 vulnerable spots and, therefore, provide a blueprint for the design of novel small-molecule inhibitors that target the invariant elements of the HIV-1 V3 loop. In the light of these observations, the strategy for antiHIV-1 drug discovery aimed at the identification of coreceptor antagonists that are able to efficiently mask these segments of the V3 loop, which are conserved in diverse viral strains, is highly challenging [2].

There are a number of promising ligands for $\mathrm{V} 3$ that, according to empirical observations, exhibit a high affinity to the HIV-1 gp120 V3 loop and, for this rea- 
son, may be implicated in the V3-based anti-AIDS drug studies (reviewed in [2]). In particular, $\beta$-galactosylceramide ( $\beta$-GalCer) forms on the surface of some susceptible host cells the primary receptor for HIV-1 alternative to CD4, which is used by the virus to enter macrophages and T-lymphocytes (e. g., [7]). Furthermore, some water soluble analogs of this glycosphingolipid have been shown to inhibit cell tropism by specific binding to V3 (e. g., [8]). In studies [8-10], the region recognized by a synthetic water soluble analog of $\beta-G a l$ Cer was mapped to the envelope gp120 amino acids 318-323, which correspond to the core V3 sequence Gly-Pro-Gly-Arg-Ala-Phe that has been previously identified to be the structurally invariant V3 site [2, 4, 6]. The findings of a study [8] have shown that synthetic analogs of $\beta$-GalCer can inhibit the HIV-1 entry both into $\mathrm{CD}^{-}{ }^{-}$and $\mathrm{CD}^{+}$cells by masking the HIV-1 V3 loop. Specific interactions of the HIV-1 V3 loop with $\beta$-GalCer were also specified in a study of Hammache and coauthors [11] by measuring surface tension variations occurring on gp120 binding to monolayers of glycolipids. In a recent study [12], glycoside analogs of $\beta$-GalCer have also been shown to block the envelope gp120 V3 loop.

Scanning the Protein Data Bank [13] shows that currently it contains the information on the V3 loops from some HIV-1 isolates as well as on a number of glycolipids including GalCer; however, there is no evidence for their complexes in this structural database (view at http://www.rcsb.org/pdb/). In the lack of empirical data, the use of computer modeling is one of the most rational modes to obtain this information, which is required for the structure-based design of novel potent antiHIV-1 drugs on the framework of $\beta$-GalCer. In this connection, an integrated computational approach involving theoretical procedures, such as quantum chemistry computations (e. g., [14]), molecular dynamics (e. g., [15]), molecular docking (e. g., [16]), free energy calculations (e. g., [17]), etc. should be of great assistance in this effort [2]. At the same time, the usage of molecular docking for imitating the process of forming the V3 loop/glycolipid complexes followed by molecular dynamics and free energy calculations may provide a rationale for the development of small molecules to block this functionally important site of the envelope gp120 protein.
The goals of this study were to build by bioinformatics tools the structural complexes of $\beta$-GalCer with the V3 loop peptides Gly-Pro-Gly-Arg/Gln-Ala-Phe imitating the most probable binding site for glycolipids [8-10] and, based on their energy and geometric parameters, to carry out the computer-aided design of $\beta-\mathrm{Gal}$ Cer water-soluble analog ( $\beta$-GalCer-WSA), which is capable of specific and effective interactions with V3, followed by its synthesis and anti-HIV-1 assay.

To reach the objectives, the following problems were solved: (i) the 3D structure of $\beta$-GalCer was generated and its dynamic characteristics were examined; (ii) the structural complexes of $\beta$-GalCer with the V3 loop peptides were built and $\beta$-GalCer-WSA, a potential HIV-1 entry inhibitor, was constructed from the analysis of intermolecular interactions, which appear in these supramolecular ensembles; (iii) the 3D structures and dynamic features of this $\beta$-GalCer-WSA were analyzed; (iv) dynamic models for the complexes of glycolipid with the V3 loop peptides were computed and their conformational stability was estimated by free energy calculations; (v) $\beta$-GalCer-WSA designed by computer modeling was synthesized and tested for antiviral activity.

With the calculated data, the binding of $\beta-$ GalCer to the V3 peptides should result in forming the stable structural complexes, and a synthetic copy of the simulated $\beta$-GalCer-WSA should preserve a strong attraction to the HIV-1 V3 loop characteristic of the native molecule. These in silico data were validated by the anti-HIV1 assay of the synthesized compound.

Materials and methods. Modeling $3 D$ structures of $\beta$-GalCer and its analog. The X-ray conformation of $\alpha$-GalCer, which appears in the complex of CD1d glycoprotein with $\beta$-2-microglobulin (PDB ID 1ZT4; http://rcsb.org/pdb/) [13], was used for computing the $3 \mathrm{D}$ structures of $\beta$-GalCer and its modified form. To design the starting model of $\beta$-GalCer, the $\alpha$-GalCer structure was subject to the following modifications by the ChemDraw computer graphics tools (http://www. cambridgesoft.com/software/): (i) $\alpha$-D-galactopyranose was substituted by $\beta$-D-galactopyranose; (ii) 4-hydroxydihydrosphingosine was transformed into sphingosine by deletion of C4-hydroxyl group and substitution for an ordinary C4-C5 bond by a double bond in trans conformation; (iii) cerotic acid $\mathrm{CH}_{3}\left(\mathrm{CH}_{2}\right)_{24} \mathrm{COOH}$ was 
converted into eicosanoic acid $\mathrm{CH}_{3}\left(\mathrm{CH}_{2}\right)_{18} \mathrm{COOH}$. The structure of $\beta$-GalCer obtained in this way was utilized to generate the starting model of water soluble analog of the glycolipid, which was designed by the deletion of its fatty acid residue.

Modeling the 3D structures of glycolipids was performed by quantum-chemical simulations using the GAMESS program package $[14,18]$. To calculate the molecular electronic configuration, the self-consistent field method of Hartree-Fock with $6-31 G^{*}$ basis set was engaged in the studies [19]. Geometric parameters of the molecules were optimized by the modified Newton-Raphson method [20]. To compute characteristic atomic charges, the Restricted Electrostatic Potential fitting procedure was used [21, 22].

Examining dynamic properties of glycolipids. Molecular dynamics (MD) simulations were involved in the studies by the Amber 10 software tools [23]. The scheme using explicit definition of the solution properties was applied. Before the MD computations, the starting structures of glycolipids were minimized by the conjugate gradient method and placed in truncated octahedral cells, allowing one to impose periodic boundary conditions on the system under consideration. Then the free space of these cells was filled by water molecules followed by heating the system from 0 to $300 \mathrm{~K}$ during $100 \mathrm{ps}$ time domain at fixed volume. In the next point, the pressure was equilibrated within 100 ps by dynamic changes of the cell linear dimensions according to the scheme of Berendsen and coauthors [24]. In the steps of heating and pressure balancing, additional constraints on the positions of glycolipids atoms were imposed by the cusp form potential using the force constant equal to $2.0 \mathrm{kcal} / \mathrm{mol}$. Subsequently, these restrictions were raised and the MD simulations were carried out in the Gibbs thermodynamic conditions within $20.5 \mathrm{~ns}$ time domain. At the same time, the first $0.5 \mathrm{~ns}$ were supposed to be the relaxation time for the structures of interest. In the final stage, clustering of the structures appearing in the MD trajectories of glycolipids was implemented.

Analysis of the MD trajectories of glycolipids made it clear that they form a limited number of structures, which, in both cases, may be divided into three clusters adequately describing their conformational mobility (Fig. 1).

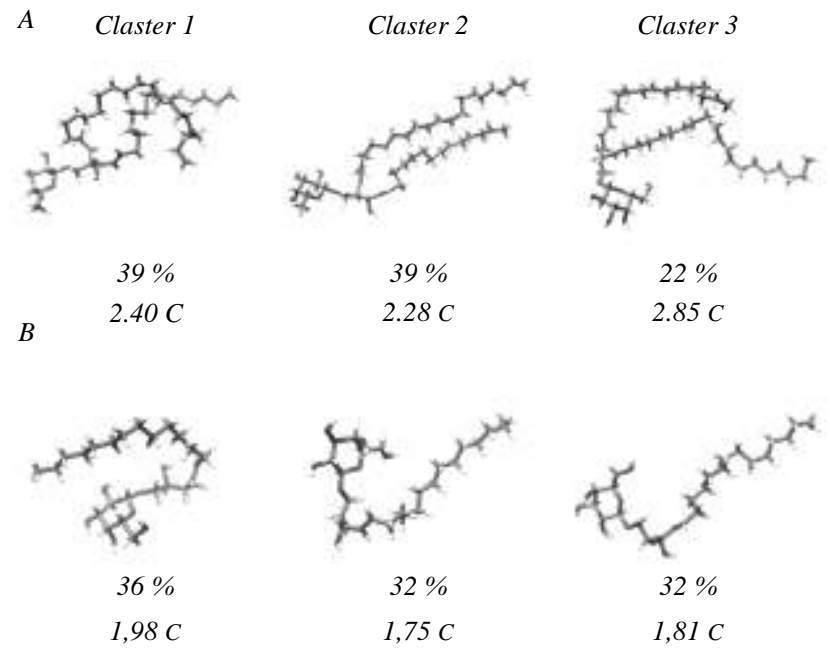

Fig. 1. 3D structures of $\beta$-GalCer $(A)$ and its water soluble analog $(B)$ obtained by subdividing the glycolipid MD trajectories into three structural clusters. The averaged structures are shown for each cluster. The populations of clusters and average distances to their centers are given below

Building dynamic structural models of the V3 loop peptides. In the calculations, the HIV-1 V3 loop was represented by its central region Gly-Pro-Gly-Gln/ Arg-Ala-Phe that greatly contributes to specific interactions of gp120 with glycolipids [8-10]. Conformations of the V3 peptides, which appear in the 3D structures of the V3 loops from the HIV-1 subtypes A (peptide Gly-Pro-Gly-Gln-Ala-Phe) [4] and $B$ (Gly-Pro-GlyArg-Ala-Phe) [5], were used as the starting points. The MD computations were carried out by the AMBER 10 package [23]. In the closing step, clustering of the calculated structures was executed.

As follows from the calculated data, the conformational mobility of the $\mathrm{V} 3$ peptides may be characterized by four clusters, the averaged structures of which (Fig. 2) were used in molecular docking simulations.

Generating structural complexes of glycolipids with the V3 peptides. To simulate the structural complexes, the UCSF DOCK 6.3 program package [25] was employed in the variant of rigid-body molecular docking. All possible molecular structures found by the MD calculations (Fig. 1 and 2) were involved in the studies to indirectly take into account their conformational flexibility. As a result of docking simulations, eight most probable complexes were selected for each V3/glyco- 


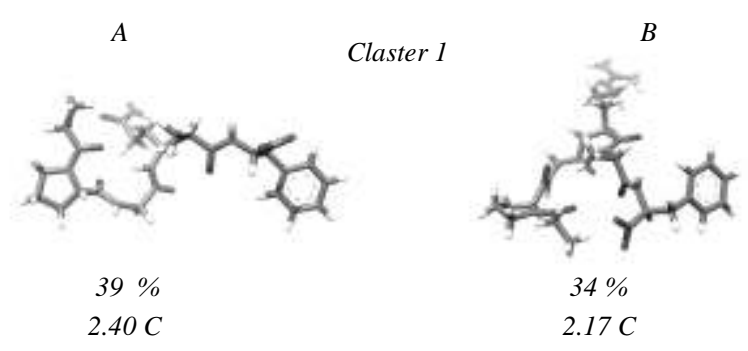

Claster 2
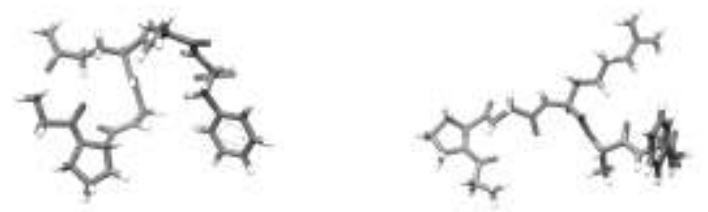

$22 \%$

$1.87 \mathrm{C}$

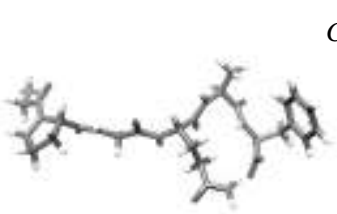

$21 \%$

$1.75 C$

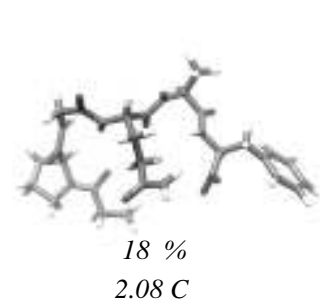

Claster 4

$2.08 \mathrm{C}$

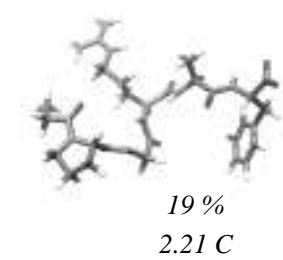

Fig. 2. The most probable 3D structures for the V3 loop peptides GlyPro-Gly-Gln-Ala-Phe $(A)$ and Gly-Pro-Gly-Arg-Ala-Phe $(B)$ according to MD simulations. The averaged structures are shown for each structural cluster. The populations of clusters and average distances to their centers are given below

lipid pair according to the values of the DOCK $6.3 \mathrm{ob}-$ jective function [25]. Subsequently, dynamic characteristics of these complexes were examined within $2.5 \mathrm{~ns}$ time domain by the MD simulations in implicit solvent. At that, the first $1.5 \mathrm{~ns}$ were assumed to be the time, which is necessary for the structure to reach the equilibrium. For every structural complex, the $1.0 \mathrm{~ns}$ segments of the MD trajectories belonging to its best-energy representatives were merged and the final trajectory obtained in this way was involved in the binding free ener- gy calculations by the MM-PB/SA method [17]. These computations were carried out by the AMBER 10 package [23].

All simulations were run on SKIF K-1000 computer cluster [26].

Synthesis of $\beta$-GalCer-WSA. $\beta$-GalCer-WSA (psychosine) was synthesized by deacylation of pig brain cerebrosides extracted by the method [27] with some modifications. Cerebrosides $(1 \mathrm{~g})$ were suspended in $18 \mathrm{ml}$ of butanol-1 in a round-bottom flask. Then the solution of $1.6 \mathrm{~g}$ potassium hydroxide in $2 \mathrm{ml}$ of water was added and the mixture was refluxed for 2 hours. The mixture was cooled and $20 \mathrm{ml}$ of isopropanol, $20 \mathrm{ml}$ of methanol, $10 \mathrm{ml}$ of chloroform and $4 \mathrm{ml}$ of $20 \%$ sulfuric acid were added. The mixture obtained was filtered and the supernatant was evaporated with toluene $(5 \mathrm{ml})$ to $15 \mathrm{ml}$ volume.

After addition of methanol $(25 \mathrm{ml})$, hexane $(25 \mathrm{ml})$ and water $(20 \mathrm{ml})$, the mixture was shaken in the separating funnel and the bottom water layer was separated and washed twice with hexane $(25 \mathrm{ml})$. Subsequently, $20 \mathrm{ml}$ of water and $20 \mathrm{ml}$ of chloroform were added; the bottom layer was separated and rotary evaporated. As a result, viscous yellowish fluid was obtained. To extract pure psyhcosine, $20 \mathrm{ml}$ of chloroform and $20 \mathrm{ml}$ of methanol were added and the solution was run through alumina and washed with $100 \mathrm{ml}$ of methanol. The overall yield was $300 \mathrm{mg}(50 \%)$.

Testing of $\beta$-GalCer-WSA for anti-HIV-1 activity in vitro. The T-lymphoblast cell line MT-4 obtained by co-cultivation of human T-cells with infected HTLV1 lymphocytes was used. The sowing doze was (45) $\cdot 10^{5}$ cells $/ \mathrm{ml}$ on the RPMI-1640 growth medium («Sigma», Germany), which included $10 \%$ fetal calf serum, $2.0 \mathrm{mM}$ of L-glutamine, $10 \mathrm{mM}$ of HEPES, $50.0 \mathrm{~g} / \mathrm{ml}$ of gentamicin sulfate and $10.0 \mathrm{~g} / \mathrm{ml}$ of tylosine tartrate) at $37^{\circ} \mathrm{C}$ in the atmosphere of $5 \%$ carbon dioxide $\left(\mathrm{CO}_{2}\right)$. The passages were repeated in every $72 \mathrm{~h}$ to determine the cell vitality by $0.2 \%$ trypan blue staining.

The HIV- $1_{z m b}$ rapid/high strain isolated from the virus-positive person living in Belarus was involved in the tests. The averaged virus titer was $6.0 \log \mathrm{TCID}_{50}$. The sample stock dilution $(10.0 \mathrm{mg} / \mathrm{ml})$ was made on distillated water and kept during four days at $4{ }^{\circ} \mathrm{C}$. The stock dilution was titrated on growth medium with 

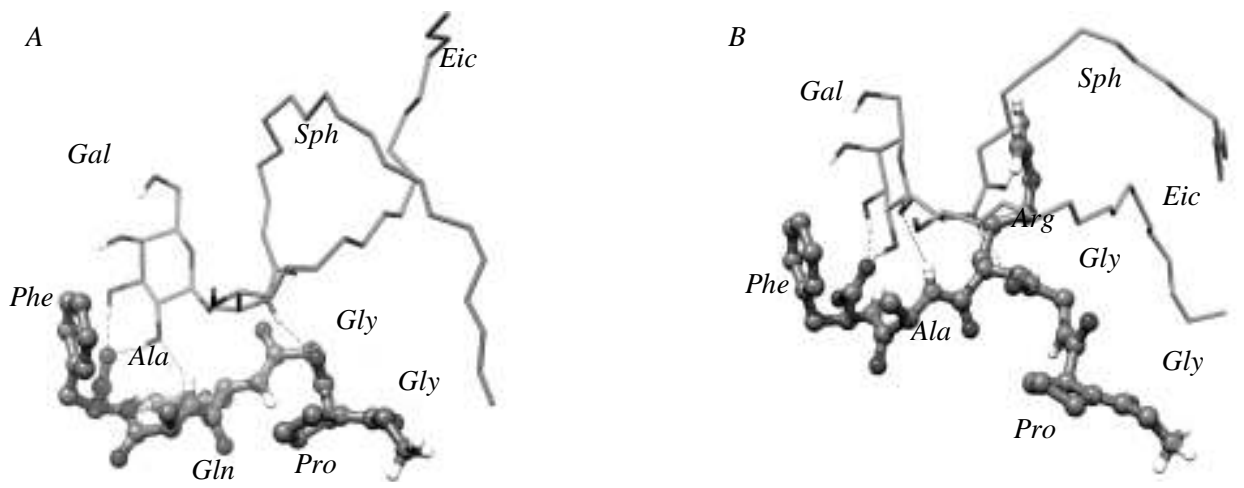

Fig. 3. Structural complexes of $\beta$-GalCer with the V3 peptides Gly-Pro-Gly-Gln-Ala-Phe $(A)$ and Gly-Pro-Gly-Arg-Ala-Phe $(B)$. H-bonds are shown by dashed lines. The averaged structures for the most probable clusters are indicated. The populations of these clusters for the V 3 peptides Gly-Pro-Gly-Gln-Ala-Phe and Gly-Pro-Gly-Arg-Ala-Phe are $47.6 \%$ and $36.8 \%$ respectively. The following designations are used: Gal galactose; Sph - sphingosine base; Eic - eicosanoic acid

5-fold step. Concentrations of the test $\beta$-GalCer-WSA ranged from $1.0 \mathrm{mg} / \mathrm{ml}$ to $0.0128 \mathrm{~g} / \mathrm{ml}$.

The anti-HIV-1 activity of the glycolipid was determined by the MTT-formazan assay [28] in the authors' version [29].

The reaction was carried out using 96-wells tissue culture panels («Sarstedt», USA) in the volume of the reaction mixture equal to 2001 per well. The results were analyzed in four days by «Plate Reader DAS A3» (Italy) at 550/630 nm wavelengths.

The trials were put into practice by a therapeutic scheme, which provides for the introduction of infectious agent to the cell culture after the addition of the test compound. In each experimental series, azidothymidine was used as a positive control.

Results and discussion. Analysis of the structural complexes of glycolipids with theHIV-1 V3 loop peptides. Fig. 3 casts light on the most probable structural complexes of $\beta$-GalCer with the V3 loop peptides generated by molecular docking followed by MD simulations. With this analysis, a key role in the formation of these complexes belongs to the conserved phenylalanine of $\mathrm{V} 3[3,30]$ as well as to the galactose residue of glycolipid. At the same time, H-bonds between sugar hydroxyl groups and polar atoms of the V3 backbone greatly contribute to the interactions of V3 with $\beta$-Gal Cer. Among these attractive forces, H-bonds of hydro$\mathrm{xyl}$ groups in $\mathrm{C} 2, \mathrm{C} 3$ and $\mathrm{C} 4$ positions of the pyranose ring with the carboxyl group of phenylalanine of $\mathrm{V} 3$ prevail in the dynamic structures of the complexes of interest. H-bonds between the amino group of the $\beta$-Gal Cer sphingosine base and the carboxyl group of glycine
3 of the V3 peptides also promote the energy stability for the supramolecular structures. In addition, H-bond between the oxygen atom of the fatty acid and the amino group of alanine of $\mathrm{V} 3$ is highly probable.

The spatial proximity of the galactose residue to the conserved phenylalanine appearing in the structure of $\beta$-GalCer complexed with the V3 peptides (Fig. 3) provides favorable conditions for making non-conventional XH $\cdots \pi \mathrm{H}$-bonds, which may be formed by XH sugar groups ( $\mathrm{X}$ designates $\mathrm{C}$ or $\mathrm{O}$ ) and overlapping $\pi$-orbitals of the Phe residue due to attractive dispersion forces [31]. These findings fall into line with those of numerous studies (see, e. g., review [32]), whereby CH... $\pi$ interactions of the galactose residue with aromatic amino acids may serve as a determining factor providing the energy stability of glycosphingolipid/protein complexes. Exactly this interaction mode, which, according to our simulations, may occur between the conserved phenylalanine of $\mathrm{V} 3$ and $\beta$-GalCer, is most likely to determine the specificity of the glycolipid binding to the envelope gp120 protein. This supposition is supported by the following rationale: the fatty acid of $\beta$-GalCer is plunged into cellular membrane, and the sugar residue is the most accessible element of the glycolipid structure (reviewed in [32]).

The patterns that $\beta$-GalCer displays on binding to proteins are also observed in the structural complexes of the free glycolipid with the V3 peptides. In these complexes, the overwhelming majority of effective contacts, which include, along with $\mathrm{XH} \cdots \pi$ interactions, intermolecular H-bonds, falls on the carbohydrate part of the molecule (Fig. 3). These findings provide 

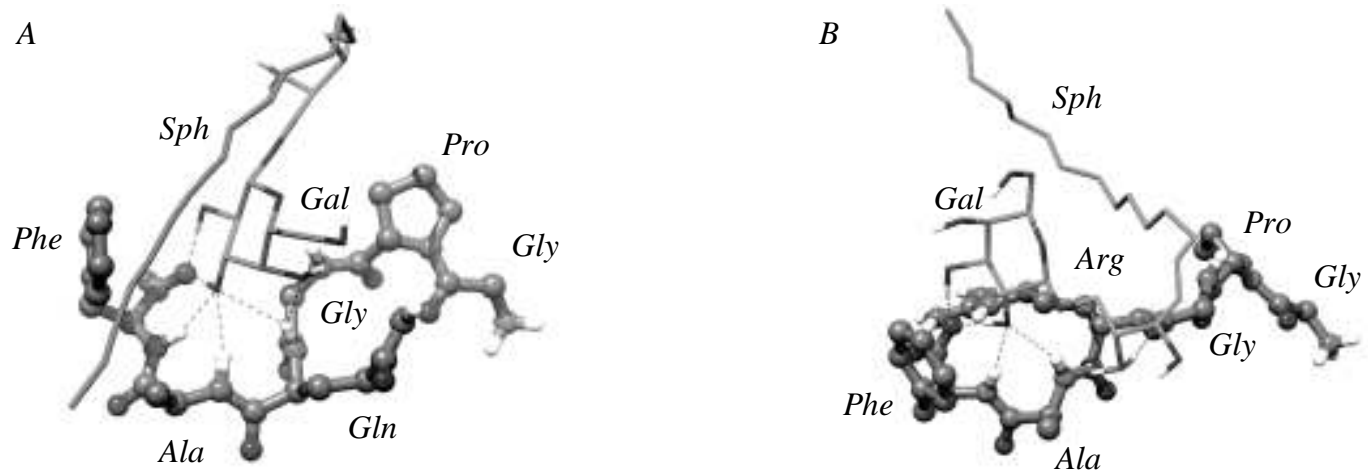

Fig. 4. Structural complexes of the V3 peptides Gly-Pro-Gly-Gln-Ala-Phe (A) и Gly-Pro-Gly-Arg-Ala-Phe $(B)$ with $\beta$-GalCer-WSA. H-bonds are shown by dashed lines. The following designations are used: $\mathrm{Gal}-$ galactose, $\mathrm{Sph}-$ sphingosine base

a structural background for designing $\beta$-GalCer-WSAs able to efficiently block the V3 loop by modifications of the fatty acid residue, which, with the calculated data, exhibits high conformational mobility and does not come in the direct contact with V3 (Fig. 3). One of such $\beta$-GalCer analogs designed with allowing for these in silico data was tested here for the ability in binding to V3 by free energy calculations.

Fig. 4 illustrates the most typical complexes of the designed analog with the V3 loop peptides in which, as with $\beta$-GalCer, the pyranose ring of galactose and the conserved Phe of V3 approach each other, and the sugar hydroxyl groups make $\mathrm{H}$-bonds with polar atoms of the V3 backbone. Along with these regularities, the structural analysis allows one to reveal specific feature characteristic of the structure of the glycolipid complexed with the V3 peptide Gly-Pro-Gly-Gln-Ala-Phe (Fig. 4, $A$ ). In this case, the sugar residue is directed at the sidechain of phenylalanine with its hydrophobic part and their spatial orientation is preserved for the major portion of the dynamic structures of this supramolecular ensemble. The high probability of forming such complexes between aromatic compounds and monosaccharides is also supported by the NMR spectroscopy data and quantum chemistry calculations [31, 33, 34].

Thus, the findings of molecular modeling clearly show that, to form the complexes with V3, the designed compound may use the structural elements identical to those, which are utilized by $\beta$-GalCer to reach these objectives. The data obtained, therefore, support the idea that this compound should keep the capacity for specific and efficient interactions with V3 characteristic of the native glycolipid. Examining the free energy of for- mation of the complexes of $\beta$-GalCer and its analog with the V3 peptides validates this supposition, which arise from the analysis of intermolecular interactions appearing in these supramolecular structures. Indeed, the design quantities of binding free energy (Table) are close to the value equal to $-10.9 \mathrm{kcal} / \mathrm{mol}$, which was calculated here from the data on the dissociation constant of the complex of $\beta$-GalCer with gp120 [35]. Nevertheless, it should be noted that our calculations concerning the glycolipid structures complexed with GlyPro-Gly-Gln-Ala-Phe result in higher values of binding energy in comparison with Gly-Pro-Gly-Arg-Ala-Phe (Table). It is possible to give the following explanation for this observation: as opposed to the uncharged glutamine, the positively charged side-chain of arginine is more likely to come in the energetically favorable contacts with polar groups of glycolipids, such as hydroxyl groups of the galactose residue and the amino group of the sphingosine base, which should increase the energy stability of the corresponding complexes.

The harmony between the calculated and the empirical data testifies to the correct choice of the computational procedures, which enabled one to generate the structural complexes that adequately describe the interactions of glycolipids with V3 despite all approximations adopted in our simulations. This conclusion is also confirmed by the findings of computer modeling, which was carried out here to generate the complexes of V3 with the modified variant of the designed $\beta$-GalCer analog where the substitution for galactose by glucose was made. Analysis of these complexes is evidence of significantly higher free energies of their formation. This fact goes with the literature data according to which 
Free energies of formation of the structural complexes of the V3 loop peptides with $\beta$-GalCer and its water soluble analog

\begin{tabular}{c|c|c|c|c|c|c|c}
\hline V3 peptide & Glycolipid & $\langle\Delta H\rangle, \mathrm{kcal} / \mathrm{mol}$ & $(\Delta H)_{\mathrm{STD}}, \mathrm{kcal} / \mathrm{mol}$ & $\langle T \Delta S\rangle, \mathrm{kcal} / \mathrm{mol}$ & $(T \Delta S)_{\mathrm{STD}}, \mathrm{kcal} / \mathrm{mol}$ & $\langle\Delta G\rangle, \mathrm{kcal} / \mathrm{mol}$ & $(\Delta G)_{\text {StD }}, \mathrm{kcal} / \mathrm{mol}$ \\
\hline \multirow{2}{*}{ GPGQAF } & $\beta$-GalCer & -27.6 & 1.1 & -18.9 & 1.2 & -8.7 & 1.6 \\
& $\beta$-GalCer-WSA & -27.5 & 3.3 & -17.8 & 0.8 & -9.7 & 3.4 \\
\multirow{2}{*}{ GPGRAF } & $\beta$-GalCer & -33.0 & 2.0 & -21.5 & 0.7 & -11.5 & 2.1 \\
& $\beta$-GalCer-WSA & -29.2 & 1.9 & -19.4 & 0.7 & -9.9 & 2.0 \\
\hline
\end{tabular}

F o o t n o t e. $\langle\Delta H\rangle$ and $\langle T \Delta S\rangle$ designate respectively the mean values of enthalpic and entropic components of free energy; $(\Delta H)_{\text {STD }}$ and $(T \Delta S)_{S T D}$ denote the standard deviations corresponding to these values; $\langle\Delta G\rangle$ and $(\Delta G)_{\text {STD }}$ denote respectively the mean values of free energies of formation of the structural complexes and the corresponding standard deviations.

glucosylceramide, unlike $\beta$-GalCer, is unable to effectively interact with gp120 [7].

Test results of $\beta$-GalCer-WSA for anti-HIV-1 activity. As a matter of record, the tested analog of $\beta$-GalCer was shown to display antiviral activity in vitro. Cellular protection rating amounts $51-53 \%$ for the glycolipid concentrations varying from 1.0 to $0.2 \mathrm{~g} / \mathrm{ml}$ (as for azidothymidine, this index ranges from 56 to $100 \%$ ). At the same time, maximal tolerant concentration aggregates $8.0 \mathrm{~g} / \mathrm{ml}$ for MT-4 cells, and chemotherapeutic index of the molecule comes to 40.0, which testifies to its high anti-HIV-1 activity.

Thus, the pilot trials of the designed $\beta$-GalCer-WSA validate the conclusion arising from the computer-aided analysis of the glycolipid structure complexed with the V3 loop peptides. In this context, the further studies of this molecule or its structural analogs by confirmatory tests for HIV-1, such as infectivity assay (e. g., [36]), p24 Elisa (e. g., (www.biochain.com)) and indirect immunofluorescence (e. g., [37]) assays, are highly challenging.

Conclusions. Computer-aided design of $\beta$-GalCerWSA presenting a potential HIV-1 entry inhibitor was first carried out here by the analysis of intermolecular interactions of the intact glycolipid with the V3 loop peptides, which imitate the core V3 sequence Gly-ProGly-Arg/Gln-Ala-Phe. The high probability of displaying the antiviral activity was predicted for the simulated molecule by estimating the free energy of formation of the structures for this $\beta$-GalCer derivative complexed with the V3 loop peptides. These in silico data are confirmed by the primary anti-HIV-1 assay of the synthesized compound. In the light of these findings, the designed analog of $\beta$-GalCer may be considered as the basic structure for simulation of its more potent struc- tural forms, inhibitory properties of which, as follows from our computations, may be correctly evaluated by bioinformatics tools. Such an approach to the development of novel, V3-based anti-HIV-1 agents, which provides for the use of the present-day computer methodologies in the first point of the studies, should give a chance to make a rational selection of drug candidates most promising for synthesis and anti-HIV-1 assays.

Acknowledgement. Theoretical part of this study was supported by grants from the Union State of Russia and Belarus (scientific program SKIF-GRID; N 4U-S/07111), as well as from the Belarusian Foundation for Basic Research (project X12-022).

А. М. Андріанов, І. В. Аніщенко, М. А. Кисіль, Ю. В. Корноушенко, В. А. Миколайович, В. Ф. Сремін, І. І. Кучеров, А. В. Тузиков

Комп'ютерне конструювання нових інгібіторів адсорбції ВІЛ-1, які блокують петлю V3 білка gр120 оболонки вірусу

Резюме

Мета дослідження - на основі аналізу міжмолекулярних взаємодій гліколіпіду $\beta$-галактозилцераміду ( $\beta$-GalCer) з центральною областю петлі V3 білка gр120 оболонки вірусу здійснити комп'ютерне конструювання водорозчинного аналога $\beta$-GalCer-nотенційного інгібітора адсорбції ВІЛ-1 - з наступним синтезом цього похідного гліколіпіду і тестуванням на противірусну активність. Методи. Комп'ютерне моделювання: квантово-хімічні розрахунки, молекулярний докінг, молекулярна динаміка і оцінка вільної енергї утворення надмолекулярних структур, а також методи хімічного синтезу та тестування на анти-ВІЛ активність. Результати. Для сконструйованого аналога $\beta$-GalCer передбачено високу ймовірність прояву противірусної активності. Дані молекулярного моделювання підтверджено результатами первинних медичних випробувань синтезованої хімічної сполуки. Висновки. Отриманий аналог $\beta$-GalCer можна розглядати як базову структуру для моделювання його більш ефективних модифікованих форм і подальшого відбору молекул, перспективних для синтезу і тестування на анти-ВІЛ активність.

Ключові слова: петля V3 білка gр120 ВIЛ-1, гліколіпіди, комn'ютерне моделювання, хімічний синтез, лікарські препарати проти СНІДу. 
А. М. Андрианов, И. В. Анищенко, М. А. Кисель, Ю. В. Корноушенко, В. А. Николаевич, В. Ф. Еремин, И. И. Кучеров, А. В. Тузиков

Компьютерное конструирование новых ингибиторов адсорбции ВИЧ-1, блокирующих петлю V3 белка gр120 оболочки вируса

\section{Резюме}

Цель исследования - на основе анализа межмолекулярных взаимодействий гликолипида $\beta$-галактозилиерамида ( $\beta$-GalCer) с иентральной областью петли V3 белка gр120 оболочки вируса осуществить компьютерное конструирование водорастворимого аналога $\beta$-GalCer - потенциального ингибитора адсорбции ВИЧ-1 последующим синтезом этого производного гликолипида и тестированием на противовирусную активность. Методы. Компьютерное моделирование: квантово-химические расчеты, молекулярный докинг, молекулярная динамика и оценка свободной энергии образования надмолекулярных структур, а также методы химического синтеза и тестирования на анти-ВИЧ активность. Результаты. Для сконструированного аналога $\beta$-GalCer предсказана высокая вероятность проявления противовирусной активности. Данные молекулярного моделирования подтверждены результатами первичных медицинских испытаний синтезированного химического соединения. Выводы. Полученный аналог $\beta$-GalCer можно рассматривать как базовую структуру для моделирования его более эффективных модифицированных форм и последующего отбора молекул, перспективных для синтеза и тестирования на анти-ВИЧ активность.

Ключевые слова: петля V3 белка gр120 ВИЧ-1, гликолипиды, компьютерное моделирование, химический синтез, лекарственные препараты против СПИДа.

\section{REFERENCES}

1. Sirois S., Sing T., Chou K. C. HIV-1 gp120 V3 loop for structure-based drug design // Curr. Protein Pept. Sci.-2005.-6, N 5.P. 413-422.

2. Andrianov A. M. Human immunodeficiency virus-1 gp120 V3 loop for anti-acquired immune deficiency syndrome drug discovery: computer-aided approaches to the problem solving // Expert Opin. Drug Discov.-2011.-6, N 4.-P. 419-435.

3. LaRosa G. J., Davide J. P., Weinhold K., Waterbury J. A., Profy A. T., Lewis J. A., Langlois A. J., Dressman G. R., Boswell R. N., Shadduk P., Holley L. H., Karplus M., Bolognesi D. P., Matthews T. J., Emini E. A., Putney S. D. Conserved sequence and structural elements in the HIV-1 principal neutralizing determinant // Science.-1990.-249, N 4971.-P. 932-935.

4. Andrianov A. M., Anishchenko I. V. Computational model of the HIV-1 subtype A V3 loop: study on the conformational mobility for structure-based anti-AIDS drug design // J. Biomol. Struct. Dynam.-2009.-27, N 2.-P. 179-193.

5. Andrianov A. M., Anishchenko I. V., Tuzikov A. V. Discovery of novel promising targets for anti-AIDS drug developments by computer modeling: application to the HIV-1 gp120 V3 loop // J. Chem. Inf. Model.-2011.-51, N 10.-P. 2760-2767.

6. Jiang X., Burke V., Totrov M., Williams C., Cardozo T., Gorny M. K., Zolla-Pazner S., Kong X. P. Conserved structural elements in the V3 crown of HIV-1 gp120 // Nat. Struct. Mol. Biol.-2010.17, N 8.-P. 955-961.

7. Bhat S., Spitalnik S. L., Gonzalez-Scarano F., Silberberg D. H. Galactosyl ceramide or a derivative is an essential component of the neural receptor for human immunodeficiency virus type 1 en- velope glycoprotein gp120 // Proc. Natl Acad. Sci. USA.-1991.88, N 16.-P. 7131-7134.

8. Fantini J., Hammache D., Delezay O., Yahi N., Andre-Barres C., Rico-Lattes I., Lattes A. Synthetic soluble analogs of galactosylceramide (GALCER) bind to the V3 domain of HIV-1 gp120 and inhibit HIV-1-induced fusion and entry // J. Biol. Chem.-1997.272, N 11.-P. 7245-7252.

9. Yahi N., Sabatier J. M., Nickel P., Mabrouk K., Gonzalez-Scarano F., Fantini J. Suramin inhibits binding of the V3 region of HIV-1 envelope glycoprotein gp120 to galactosylceramide, the receptor for HIV-1 gp120 on human colon epithelial cells // J. Biol. Chem.-1994.-269, N 39.-P. 24349-24353.

10. Yahi N., Sabatier J. M., Baghdiguian S., Gonzalez-Scarano F., Fantini J. Synthetic multimeric peptides derived from the principal neutralization domain (V3 loop) of human immunodeficiency virus type 1 (HIV-1) gp120 bind to galactosylceramide and block HIV-1 infection in a human CD4-negative mucosal epithelial cell line // J. Virol.- 1995.-69, N 1.-P. 320-325.

11. Hammache D., Pironi G., Yahi N., Delezay O., Koch N., Lafont $H$., Tamalet C., Fantini J. Specific interaction of HIV-1 and HIV2 surface envelope glycoproteins with monolayers of galactosylceramide and ganglioside GM3 // J. Biol. Chem.-1998.-273, N 14.-P. 7967-7971.

12. Garg H., Francella N., Tony K. A., Augustine L. A., Barchi J. J. Jr., Fantini J., Puri A., Mootoo D. R., Blumenthal R. Glycoside analogs of beta-galactosylceramide, a novel class of small molecule antiviral agents that inhibit HIV-1 entry // Antiviral Res.2008.-80, N 1.-P. 54-61.

13. Berman H. M., Westbrook J., Feng Z., Gilliland G., Bhat T. N., Weissig H., Shindyalov I. N., Bourne P. E. The protein data bank // Nucleic Acids Res.-2000.-28, N 1.-P. 235-242.

14. Schmidt M. W., Baldridge K. K., Boatz J. A., Elbert S. T., Gordon M. S., Jensen J. H., Koseki S., Matsunaga N., Nguyen K. A., Su S. J., Windus T. L., Dupuis M., Montgomery J. A. General Atomic and Molecular Electronic Structure System (GAMESS) // J. Comput. Chem.-1993.-14.-P. 1347-1363.

15. Berendsen H. J. C., van der Spoel D., van Drunen R. GROMACS: A message-passing parallel molecular dynamics implementation // Comp. Phys. Commun.-1995.-91, N 1-2.-P. 43-56.

16. Taylor R. D., Jewsbury P. J., Essex J. W. A review of proteinsmall molecule docking methods // J. Comput. Aided Mol. Des.2002.-16, N 3.-P. 151-166.

17. Massova I., Kollman P. A. Computational alanine scanning to probe protein-protein interactions: a novel approach to evaluate binding free energies // J. Am. Chem. Soc.-1999.-121, N 36.P. 8133-8143.

18. Gordon M. S., Schmidt M. W. Advances in electronic structure theory: GAMESS a decade later // Theory and applications of computational chemistry: the first forty years / Eds C. E. Dykstra et al.-Amsterdam: Elsevier, 2005.-P. 1167-1189.

19. Wang J., Wolf R. M., Caldwell J. W., Kollman P. A., Case D. A. Development and testing of a general amber force field // J. Comput. Chem.-2004.-25, N 9.-P. 1157-1174.

20. He J. H. A modified Newton-Raphson method // Num. Methods Biomed. Eng.-2004.-20, N 10.-P. 801-805.

21. Bayly C. I., Cieplak P., Cornell W. D., Kollman P. A. Well-behaved electrostatic potential based method using charge restraints for determining atom-centered charges: the RESP model // J. Phys. Chem.-1993.-97, N 40.-P. 10269-10280.

22. Cornell W. D., Cieplak P., Bayly C. I., Kollmann P. A. Application of the RESP charges to calculate conformational energies, hydrogen bond energies, and free energies of salvation // J. Am. Chem. Soc.-1993.-115.-P. 9620-9631. 
23. Case D. A., Darden T., Cheatham T. E., III, Simmerling C. L., Wang J., Duke R. E., Luo R., Crowley M., Walker R. C., Zhang W., Merz K. M., Wang B., Hayik S., Roitberg A., Seabra G., Kolossvary I., Wong K. F., Paesani F., Vanicek J., Wu X., Brozell S. R., Steinbrecher T., Gohlke H., Yang L., Tan C., Mongan J., Hornak V., Cui G., Mathews D. H., Seetin M. G., Sagui C., Babin V., Kollman P. A. AMBER 10.-San Francisco: Univ. of California, 2008.

24. Berendsen H. J. C., Postma J. P. M., Van Gunsteren W. F., Dinola A., Haak J. R. Molecular dynamics with coupling to an external bath // J. Chem. Phys.-1984.-81, N 8.-P. 3684-3690.

25. Lang P. T., Brozell S. R., Mukherjee S., Pettersen E. F., Meng E. C., Thomas V., Rizzo R. C., Case D. A., James T. L., Kuntz I. D. DOCK 6: Combining techniques to model RNA-small molecule complexes // RNA.-2009.-15, N 6.-P. 1219-1230.

26. Ablameyko S. V., Abramov S. M., Anishchanka U. V., Medvedev S. V., Paramonov N. N., Tchij O. P. SKIF supercomputer configurations.-Minsk: United Institute of Informatics Problems, 2005.-170 p.

27. Radin N. S. Preparative isolation of cerebrosides (galactosyl and glucosyl ceramide) // J. Lipid Res.-1976.-17, N 3.-P. 290-293.

28. Mosmann T. Rapid colorimetric assay for cellular growth and survival: application to proliferation and cytotoxicity assays // J. Immunol. Methods.-1983.-65, N 1-2.-P. 55-63.

29. Kucherov I. I., Rytik P. G., Podolskaya I. A. Current problems of human's infectious pathology (virology, microbiology, immunology, epidemiology, clinic) // Infectious diseases 1998-2000 (20-22 Nov. 2001, Minsk).-Minsk, 2001.-P. 195-200.

30. Tian H., Lan $C$., Chen $Y$. H. Sequence variation and consensus sequence of V3 loop on HIV-1 gp120 // Immunol. Lett.-2002.83, N 3.-P. 231-233.
31. Kumar R. M., Elango M., Subramanian V. Carbohydrate-aromatic interactions: the role of curvature on $\mathrm{XH}$...pi interactions // J. Phys. Chem. A.-2010.-114, N 12.-P. 4313-4324.

32. Fantini J., Yahi N. Molecular insights into amyloid regulation by membrane cholesterol and sphingolipids: common mechanisms in neurodegenerative diseases // Expert Rev. Mol. Med.2010.-12, e27.

33. del Carmen Fernandez-Alonso M., Canada F. J., Jimenez-Barbero J., Cuevas $G$. Molecular recognition of saccharides by proteins. Insights on the origin of the carbohydrate-aromatic interactions // J. Am. Chem. Soc.-2005.-127, N 20.-P. 7379-7386.

34. Diaz M. D., Fernandez-Alonso M. C., Cuevas G., Canada F.J., Jimenez-Barbero J. On the role of aromatic-sugar interactions in the molecular recognition of carbohydrates: A 3D view by using NMR // Pure Appl. Chem.-2008.-80, N 8.-P. 1827-1835.

35. Harouse J. M., Bhat S., Spitalnik S. L., Laughlin M., Stefano K., Silberberg D. H., Gonzalez-Scarano F. Inhibition of entry of HIV1 in neural cell lines by antibodies against galactosyl ceramide // Science.-1991.-253, N 5017.-P. 320-323.

36. Jones J., Whitford W., Wagner F., Kutsch O. Optimization of HIV1 infectivity assays // Biotechniques.-2007.-43, N 5.-P. 589-590, 592, 594.

37. Kiptoo M. K., Mpoke S. S., Ng'ang'a Z. W. New indirect immunofluorescence assay as a confirmatory test for human immunodeficiency virus type $1 / /$ East Afr. Med. J.-2004.-81, N 5.P. 222-225.

Received 30.01.12 